\title{
PERGESERAN FUNGSI DAN TERITORIALITAS PADA RUANG RUMAH ADAT CIKONDANG
}

\author{
Annisaa Kurnia W., Imam Santosa \\ (Email: annisaakurnia10@gmail.com, imamzsantosa@gmail.com) \\ Magister Desain \\ Fakultas Seni Rupa dan Desain \\ Institut Teknologi Bandung \\ Jalan Ganesha No.10, Lb. Siliwangi, Kecamatan Coblong, Kota Bandung
}

\begin{abstract}
ABSTRAK
Penggunaan fungsi ruang-ruang dalam Rumah Adat Cikondang mengalami perubahan sejak tahun 1980 oleh pemerintah sebagai cagar budaya. Sejak ditetapkannya sebagai cagar budaya, masyarakat adat dan juga ketua adat berupaya untuk membuka diri dengan dunia luar. Rumah Adat Cikondang yang pada awalnya merupakan tempat tinggal bagi keluarga juru kunci atau ketua adat, saat ini telah menjadi salah satu wujud peninggalan yang masih tersisa sebagai peninggalan fisik bersifat simbolis bagi keberadaan kampung adat secara utuh. Seiring berjalannya waktu, segala kegiatan telah mengalami perubahan fungsi, seperti tempat kegiatan bermusyawarah warga adat setempat, tempat berkunjung bagi para wisatawan serta tempat dilaksanakannya ritual-ritual adat. Seluruh kegiatan tersebut merupakan kegiatan yang rutin dilaksanakan di Kampung Adat Cikondang saat ini. Rumah adat tetap dilestarikan sebagai bentuk penghormatan terhadap leluhur, maupun warga luar yang senantiasa berkunjung. Kegiatan yang berlangsung dalam ruang rumah adat telah menjadi suatu bentuk perubahan interaksi antara pengguna dengan teritori atau wilayah, dengan demikan penelitian ini bertujuan untuk mengetahui pegeseran fungsi ruang dahulu dan saat ini, mengetahui perubahan teritori ruang pada rumah adat dan faktor-faktor yang menjadikan suatu teritorialitas itu terjadi. Penelitian ini merupakan penelitian deskriptif analisis dengan menggunakan pendekatan fenomenologi, dimana dapat diketahui suatu kenyataan yang terjadi pada pergeseran fungsi, perubahan zona teritori dan faktor-faktor yang membentuk teritorialitas itu sendiri setelah itu dianalisis menggunakan empat tahapan yang biasa digunakan dalam fenomenologi. Teori yang dikemukakan oleh Hall dan Altman dioperasionalisasikan pada analisis perubahan teritori yang diawali pergeseran fungsi, sedangkan teori yang dikemukakan oleh Brower digunakan juga sebagai teori yang memperkuat terjadinya teritorialitas dalam ruang. Hasil penelitian menunjukkan bahwa tidak hanya pergeseran fungsi, keterkaitan sosial, interaksi antarsesama pengguna, dan mekanisme defensif (pengaturan batas-batas ruang) yang menjadikan teritori ruang dalam rumah adat berubah, melainkan terdapat protokoler atau aturan-aturan adat istiadat yang harus dipatuhi sebagai tanda penghormatan dan upacara-upacara ritual adat tertentu.
\end{abstract}

Kata Kunci: pergeseran fungsi ruang, teritorialitas, rumah adat, Cikondang

\section{ABSTRACT}

The use of the functions of spaces in Cikondang Traditional House has changed since 1980 by the government as a cultural heritage. This place was established as a cultural heritage since indigenous peoples and traditional leaders tried to open themselves up to the outside. Cikondang Traditional House 
was original house for the family of the traditional leader and now become a cultural heritage to remain the legacy as a symbolic physical legacy for the existence of the traditional village. As time goes by, the activities have a change in function, such as deliberation activities for local people, the tourists and traditional rituals. All of these activities are routinely carried out in Cikondang Traditional Village. The Traditional house as a function for conducting customary deliberation, tourist visits, and ritual celebrations was carried out as a form of respect for ancestors and outsiders who always visit this place. All of the activities that take place in traditional house spaces has become a form of change in interaction between users and territories, thus this research aims to determine the shift in past and present, to determine changes in spatial territory ang the factors become territoriality. This research is a descriptive analysis using a phenomenological approach which can be seen a fact that occurs in a shift in function, a change in the territorial zone and the factors that make up the territoriality itself. This research analyzed using four steps that commonly used in phenomenology. The territory theory by Hall and Altman used in the analysis of territorial change which begins with a function shift, while the theory forward by Brower also used as a theory that strengthens territoriality in spaces. The result showed that not only the function shift, social cohesiveness, interaction between the users and defensive mechanisms that make the space territories in a traditional house change, but there are protocols or customary rules that must be obeyed as a respect sign and traditional rituals.

Keywords: shifting space function; territoriality; traditional house; Cikondang

\section{PENDAHULUAN}

Rumah Adat Cikondang merupakan salah satu peninggalan cagar budaya yang berlokasi di Kampung Adat Cikondang, Desa Lamajang, Kecamatan Pangalengan, Kabupaten Bandung, Jawa Barat. Terdapat enam puluh rumah pada tahun 1940-an di Kampung Adat Cikondang, namun sekitar tahun 1942 terjadi peristiwa kebakaran yang meyebabkan hampir seluruh rumah adat terbakar, kecuali rumah adat milik seorang juru kunci (ketua adat) Kampung Adat Cikondang (Rif'ati dan Sucipto, 2002). Berdasarkan hasil wawancara dengan salah seorang warga kampung adat, Aki Enjoh berusia 98 tahun, penyebab peristiwa kebakaran tersebut disebabkan oleh seorang warga yang sedang membakar kayu termasuk dedaunan kering, lalu membiarkannya sehingga api terus menyala dan menyambar rumah-rumah warga sampai tersisa satu rumah adat kepunyaan juru kunci (ketua adat) (Enjoh, wawancara pribadi. 4 Februari 2020). 


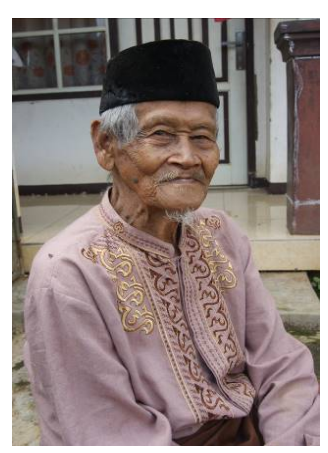

Gambar 1. Seorang saksi sejarah peristiwa kebakaran di Kampung Adat Cikondang Sumber: Dokumentasi penulis, Februari 2020.

Nilai-nilai kearifan lokal pada Kampung Adat Cikondang memiliki tingkat signifikansi keberadaan yang cukup penting bagi masyarakat adat. Kegiatan ritual, musyawarah adat, yang selalu dilaksanakan dalam rumah adat menjadi salah satu penghormatan terhadap leluhur maupun warga adat setempat. Ritual-ritual adat yang senantiasa dilakukan diantaranya, Wuku Taun, Hajat Lembur, Ngaruat Bumi, Ruat Solokan, Ruat Hajat, tradisi Upacara Pertanian, Tradisi Upacara Hajat Paralon. Seluruh kegiatan tersebut dilaksanakan sebagai wujud rasa syukur kepada Tuhan Yang Maha Esa, penghormatan terhadap leluhur dan terhindar dari segala marabahaya.

Rumah adat pada awalnya digunakan sebagai tempat tinggal bagi juru kunci beserta anak dan istri, namun dengan seiring perkembangan zaman fungsi tersebut beralih sebagai peninggalan cagar budaya, tempat wisata edukasi budaya dan agama, tempat untuk diadakannya musyawarah antar masyarakat adat, serta tempat berlangsungnya kegiatan pertunjukan kesenian. Pemanfaatan penggunaan ruang-ruang dalam rumah adat sebagai tempat menjalankannya aktivitas digunakan semaksimal mungkin walaupun terdapat perubahan fungsi. Perubahan fungsi yang sangat terlihat tidak menjadikan kegiatankegiatan ritual adat hilang begitu saja, namun sebagai penghormatan kepada leluhur segala jenis perayaan tradisi adat dilaksanakan di rumah adat dan masyarakat tetap mematuhi aturan yang ada. Rumah adat digunakan secara turun temurun dari generasi pertama hingga saat ini,karena kegiatan yang berhubungan dengan tradisi adat sampai 
dengan persiapannya tidak diperbolehkan keluar dari rumah adat, kecuali jika ada bagian dari pelaksanaan ritual tertentu yang memang diharuskan berada di luar rumah adat (Juhana, wawancara pribadi. 2 Februari 2020).

Kegiatan manusia pada dasarnya membutuhkan wadah atau setting kegiatan yang berupa ruang. Kondisi tersebut menjadikan setiap individu atau kelompok telah membentuk area (teritori tersendiri. Kebutuhan privasi ,pribadi ruang, dan wilayah bersifat universal dan berkontribusi bagi kebutuhan manusia lainnya, seperti keamanan, afiliasi, dan harga diri (Lang,1987). Konsep territorial secara menyeluruh merujuk pada setting perilaku teritorial manusia sebagai ruang yang terbatasi dalam berinteraksi secara individu dan kelompok yang bersifat intra spesifik, dimana seseorang ingin menyuarakan diri, memiliki, menggunakan, menjaga, melakukan pertahanan dan kontrol khusus (Lianto, 2015). Suatu teritori timbul karena interaksi masyarakat dengan lingkungannya yang diwujudkan dalam kegiatan dan tempatnya antara lain berupa upaya-upaya pengamanan dan pemeliharaan tempat tersebut dari gangguan orang lain atau karena pengguna individu atau kelompok melakukan kegiatan pada tempat tertentu (Burhanuddin, 2015).

Peran ruang dalam rumah adat menjadi sangat penting karena keberadaannya tidak dapat dihilangkan begitu saja. Perubahan fungsi pada rumah adat yang dahulu sebagai tempat tinggal juru kunci saat ini dilestarikan menjadi suatu tempat atau wadah bagi masyarakat setempat sebagai sarana untuk beraktivitas, kunjungan wisatawan dan juga ritual-ritual adat. Oleh karena itu, hal tersebut menjadi sesuatu yang menarik dalam penelitian ini. Berdasarkan latar belakang tersebut, penelitian ini fokus pada dua rumusan permasalahan yaitu bagaimana pergeseran fungsi yang menjadikan perubahan pada klasifkasi teritori ruang pada rumah adat dan faktor-faktor penguat yang menyebabkan teritorialitas itu terjadi dalam ruang-ruang rumah adat. Tujuan penelitian yang dicapai adalah untuk mengetahui pergeseran fungsi yang terjadi dahulu dan saat ini, mengetahui perubahan 
teritori ruang pada rumah adat dan faktor-faktor yang menjadikan suatu teritorialitas itu terjadi.

\section{METODE PENELITIAN}

Lokasi penelitian ini berlokasi di Kampung Adat Cikondang yang berada di Desa Lamajang, Kecamatan Pangalengan, Kabupaten Bandung, Propinsi Jawa Barat. Lokasi penelitian terdapat dalam kawasan Kampung Adat Cikondang yang masih memiliki satu rumah adat. Penelitian ini merupakan penelitian deskriptif kualitatif dengan pendekatan fenomenologi. Pendekatan fenomenologi ini dilakukan dengan cara mengungkap suatu fenomena pengalaman yang dialami oleh suatu individu atau kelompok dalam suatu peristiwa. Pendekatan fenomenologi dalam penelitian ini mengacu dengan suatu kenyataan yang terjadi pada pergeseran fungsi, perubahan zona teritori rumah adat dan memahami keterkaitannya dengan faktor-faktor yang membentuk teritorialitas itu sendiri. Sumber data primer atau sumber data utama diperoleh dari hasil wawancara secara langsung saat penelitian yang dicatat melalui catatan-catatan tertulis, pengamatan langsung (observasi) dari tindakan-tindakan masyarakat adat setempat dalam rumah adat, pengambilan foto, sketsa rumah adat. Sumber data sekunder atau sumber data kedua diperoleh dari dokumen-dokumen di tempat penelitian setempat mengenai Kampung Adat Cikondang, sumber referensi buku-buku yang terkait dengan teori yang digunakan, serta referensi jurnal-jurnal ilmiah terkait dengan penelitian penulis.

Teknik pengumpulan data penelitian ini dilakukan dengan cara wawancara mendalam (in depth interview) dengan narasumber, yaitu juru kunci di Kampung Adat Cikondang dan masyarakat adat setempat. Selain itu dilakukan observasi secara langsung pada lokasi penelitian yaitu di rumah adat Cikondang dengan alat bantu sebagai instrumen penelitian, pengumpulan data dengan kamera DSLR untuk pengambilan gambar, perekam suara handphone saat wawancara dan buku sketsa. Analisis data yang dilakukan pada penelitian ini berbentuk deskriptif analisis yang akan dianalisis dengan menggunakan teori mengenai Teritori yang dikemukakan oleh Hall (1969) dan Altman (1976) dan teori mengenai faktor- 
faktor yang menjadikan suatu teritorialitas dalam rumah adat yang dikemukakan oleh Brower (1976). Analisis data pada tahapan penelitian fenomenologi dilakukan melalui empat tahap, yaitu tahap horizonalisasi yang merupakan tahap dimana penulis mempersiapkan draft wawancara untuk mengetahui pengalaman-pengalaman yang dialami masyarakat setempat terkait dengan pergeseran fungsi pada rumah adat, tahap deskripsi tekstural yang merupakan tahap dimana peneliti memfokuskan pada pengalaman interaksi atau tindakan masyarakat setempat terhadap masyarakat setempat lainnya dan masyarakat luar dalam rumah adat, tahap deskripsi struktural merupakan tahap yang dilakukan peneliti untuk melihat pengalaman, tindakan bahkan peristiwa yang meliputi waktu, dan tempat (ruang-ruang dalam rumah adat), tahap terakhir merupakan tahap gambaran makna akan fenomena dari tahap struktural dan tekstural.

\section{Teori Teritori dan Teritorialitas}

Istilah mengenai teritori atau wilayah diartikan sebagai daerah kekuasaan, pemerintahan, penngawasan, lingkungan daerah (Kamus Besar Bahasa Indonesia dalam Nur'aini \& Ikaputra, 2019: 13). Teritori menurut Pastalan (1970) merupakan ruang terbatas yang digunakan oleh individu atau kelompok yang dipertahankan sebagai tempat ekslusif (Nur'aini \& Ikaputra, 2019: 13).

Teritorialitas adalah suatu tingkah laku yang diasosiasikan pemilikan atau tempat yang ditempatinya atau area yang sering melibatkan ciri pemilikannya dan pertahanan dari gangguan luar (Nurhamsyah, 2016: 5). Teritorialitas menunjukkan hubungan individu atau kelompok dengan setting fisiknya, yang dicirikan oleh rasa memiliki dan upaya kontrol tehadap penggunaan interaksi yang tidak diinginkan melalui kegiatan penempatan, mekanisme defensif dan keterikatan. Faktor budaya mempengaruhi sikap teritorialitas. Kontrol terhadap territorial memungkinkan untuk mencapai tingkat privasi dan keintiman yang berbeda dari tingkat tinggi hingga tingkat rendah (Brower 1976 dalam Nur'aini \& Ikaputra, 2019: 14). Tingkat privacy dengan territorial adalah bahwa perlakuan untuk memperoleh 
privacy dengan cara membuat batasan-batasan fisik seperti itu secara tidak langsung membentuk adanya penandaan teritori (Hadinugroho, 2002: 4).

Pengertian kontrol lebih lanjut dijelaskan oleh Altman (1975) sebagai mekanisme mengatur batas antara orang yang satu dengan lainnya melalui penandaan untuk menyatakan bahwa tempat tersebut ada yang memilikinya. Klaim atas ruang merupakan bagian dari hak manusia dalam penggunaan ruang apabila berada pada area yang merupakan hak dari pelaku klaim dan klaim tersebut dapat dimaknai sebagai gabungan dari hak akses, kebebasan bertingkah laku dalam menyatakan kepemilikan terhadap suatu ruang serta dapat dipicu oleh keinginan pribadi maupun untuk kepentingan kelompok (Indriani, 2019:34).

Teori tersebut diperjelas kembali oleh Brower pada tahun (1976) dimana teritorialitas bukanlah satu-satunya mekanisme untuk mengendalikan interaksi sosial, namun dapat juga dikendalikan dengan protokoler dan ritual. Faktor budaya memainkan peranan penting dalam penandaan teritori manusia (Hadinugroho, 2002: 4). Faktor budaya mempengaruhi sikap teritorialitas, karena secara budaya terdapat perbedaan sikap teritori yang dilatarbelakangi oleh budaya seseorang. Begitu juga apabila seseorang mengunjungi ruang publik yang jauh berada diluar kultur budayanya secara langsung juga berbeda sikap teritorinya (Fatimah, 2010: 3).

\section{Klasifikasi Teritori}

Pengklasifikasian teritori dilakukan oleh Altman (1975) dan Hall (1969) menjadi ke dalam tiga klasifikasi, yaitu:

\section{Teritori Primer}

Teritori primer rasa kepemilikan individual atau suatu kelompok sangat tinggi, cenderung dimiliki secara permanen. Pemilik memiliki kontrol secara penuh pada area tersebut dan gangguan merupakan suatu hal yang serius dan menjadi perhatian. 


\section{Teritori Sekunder}

Teritori sekunder ini tidak dimiliki oleh individu atau kelompok, tetapi sering digunakan dan orang lain pun diperbolehkan menggunakan area tersebut. Rasa memiliki pada teritori sekunder bersifat sedang.

\section{Teritori Publik}

Teritori publik tidak dimiliki oleh individu ataupun suatu kelompok. Rasa kepemilikan pada teritori ini tergolong rendah dan sangat sulit mengontrol area ini. Area publik digunakan oleh sejumlah orang yang sangat banyak. Faktor budaya mempengaruhi sikap teritorialitas, karena secara budaya terdapat perbedaan sikap teritori yang dilatarbelakangi oleh budaya seseorang. Begitu juga apabila seseorang mengunjungi ruang publik yang jauh berada diluar kultur budayanya secara langsung juga berbeda sikap teritorinya (Fatimah, 2010: 3).

\section{Operasionalisasi Teori}

Penelitian ini menggunakan teori teritori yang dikemukakan oleh Hall dan Altman bahwa klasifikasi teori dalam suatu ruang memiliki tiga jenis, yaitu teritori primer, teritori sekunder dan teritori publik. Pada analisis pertama, peneliti akan membahas terlebih dahulu pergeseran fungsi yang terjadi pada ruang-ruang rumah adat. Setelah itu pada analisis kedua dilakukan pengklasifikasian teritori dan perubahannya dalam bentuk tabel. Pada analisis ketiga peneliti menjabarkan faktor-faktor yang menjadikan teritorialitas itu terjadi dan menganalisis hubungan atau keterkaitan diantara faktor-faktor tersebut serta kekuatan teori dimana terdapat faktor protokoler dan ritual yang diperkuat oleh Brower.

\section{PEMBAHASAN}

\section{Tata Ruang Rumah Adat Cikondang}

Rumah Adat Cikondang berada di Kampung Adat Cikondang, Desa Lamajang, Kecamatan Pangalengan, Kabupaten Bandung. Kampung Adat Cikondang bisa ditempuh sejauh 30 kilometer dari Kota Bandung, 20 kilometer dari Kabupaten Bandung, 8 kilometer dari 
Kecamatan Pangalengan dan sekitar 1 kilometer dari Desa Lamajang. Desain bangunan rumah adat berbentuk rumah panggung, sama seperti rumah adat Sunda pada umumnya. Terdapat ruang tengah atau bale dan dua kamar. Satu kamar merupakan kamar yang digunakan hanya untuk juru kunci (kuncen) sebagai tempat ibadah dan menyimpan barang-barang pusaka, sedangkan satu kamar lainnya merupakan kamar atau ruangan yang difungsikan sebagai tempat penyimpanan beras (goah) termasuk sesaji. Goah yang merupakan tempat penyimpanan beras memiliki makna suatu persembahan dan penghormatan terhadap Dewi Sri atau Dewi Padi yang telah memberikan sumber kemakmuran hidup. Ruang Tengah atau bale menyatu dengan area dapur. Ruang tengah biasanya digunakan juru kunci untuk menerima tamu yang datang berkunjung dan sekaligus digunakan untuk acara ritual yang rutin diadakan setiap tahunnya.

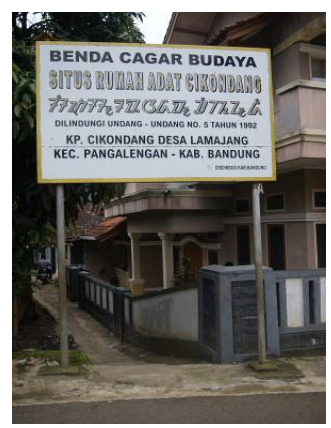

Gambar 2. Akses masuk Kampung Adat Cikondang

Sumber: Dokumentasi penulis, Februari 2020.

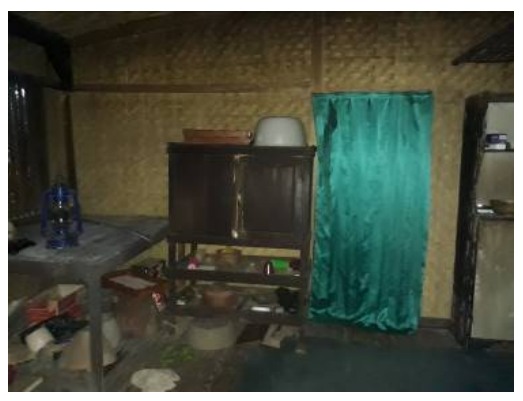

Gambar 4. Ruang goah (ditutup dengan tirai sisi kiri) Sumber: Dokumentasi Penulis, Februari 2020

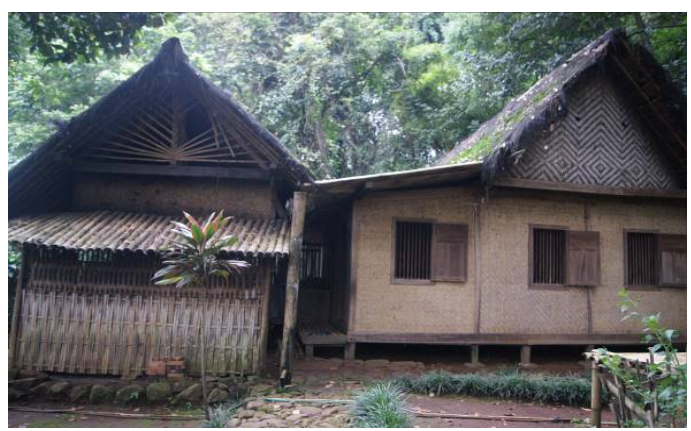

Gambar 3. Rumah adat Cikondang Sumber: Dokumentasi penulis, Februari 2020

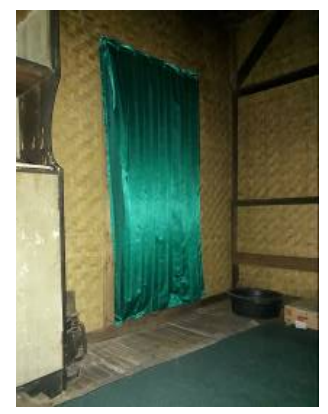

Gambar 5. Ruang kamar juru kunci di sisi kanan

Sumber:. Dokumentasi Penulis, Februari 2020 


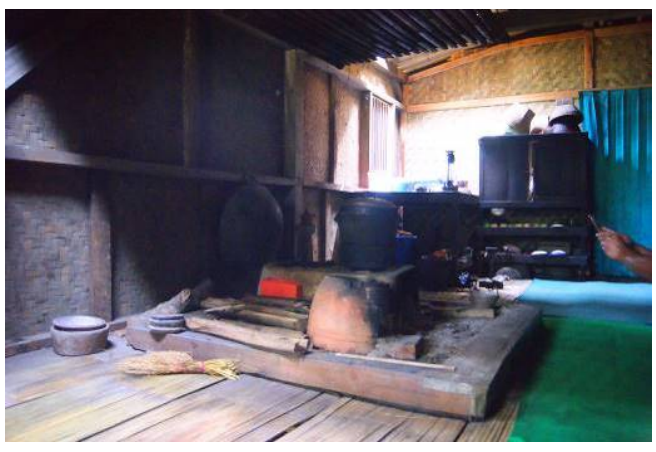

Gambar 6. Area pawon dalam Sumber:. Dokumentasi Penulis, Februari 2020

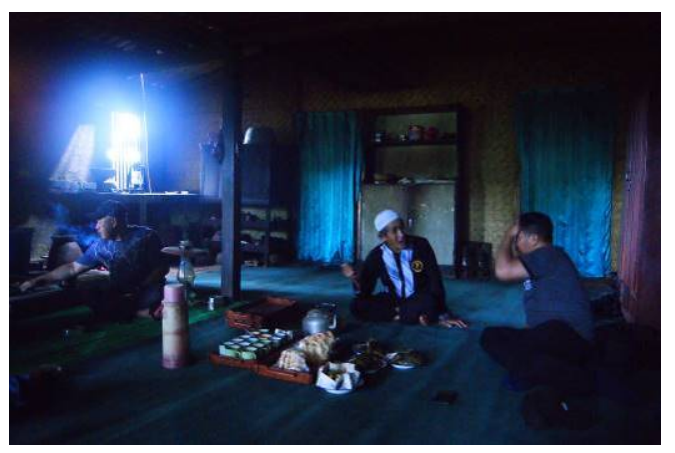

Gambar 7. Area ruang tengah Sumber:. Dokumentasi Penulis, Februari 2020

Terdapat pula dapur atau pawon di bagian dalam ruangan yang hanya digunakan untuk menanak nasi dan memasak air. Bagian sudut ruangan, terdapat sebuah lemari dan meja yang digunakan untuk menyimpan perlengkapan memasak dan peralatan makan dan minum. Perlengkapan memasak ini digunakan saat melakukan persiapan ritual upacara adat seperti halnya saat Wuku Taun 15 Muharram, begitu juga dengan piring dan gelas yang digunakan untuk menjamu para tamu. Seluruh peralatan memasak dan peralatan makan minum merupakan peralatan khas tradisional Sunda. Seluruh peralatan makan dan minum terbuat dari bahan seng, karena peralatan yang sudah modern masih dianggap tabu oleh masyarakat setempat.

Sebelum memasuki rumah adat, terdapat dapur atau pawon tambahan yang digunakan untuk memasak, karena dapur bagian dalam hanya boleh digunakan untuk menanak nasi dan memasak air. Pada bagian luar, tepatnya di depan dapur luar terdapat pula sebuah bale-bale yang digunakan untuk menyimpan peralatan makan dan minum tambahan saat dilaksanakannya ritual upacara adat. Tidak jauh dari bale-bale terdapat lumbung padi atau leuit, yaitu tempat yang digunakan untuk menyimpan padi hasil panen sawah adat. Kamar mandi atau yang disebut juga dengan tampian terletak 5 meter dari Rumah Adat. Hal ini disebabkan karena rumah dianggap sebagai area yang suci. 


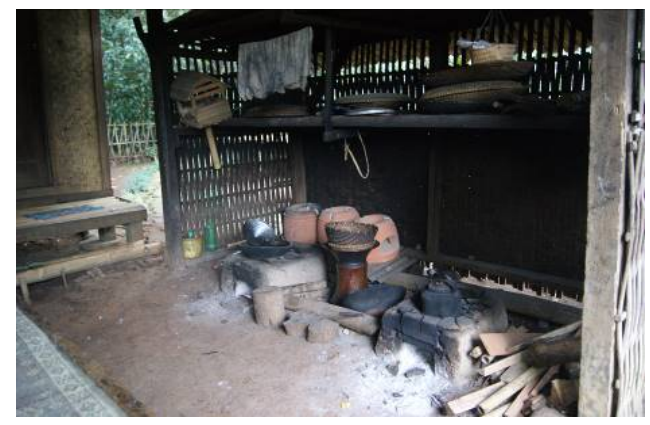

Gambar 8. Area pawon luar Sumber: Dokumentasi penulis, Februari 2020

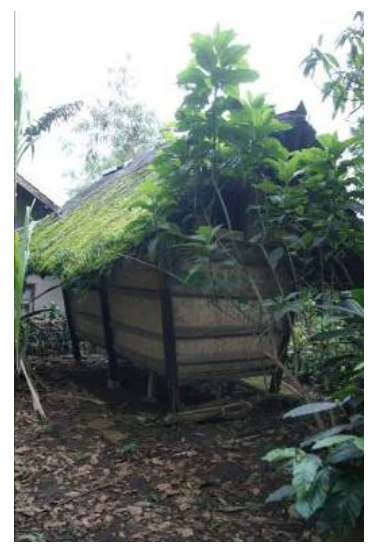

Gambar 10. Leuit (terpisah dengan rumah adat) Sumber:. Dokumentasi penulis, Februari 2020

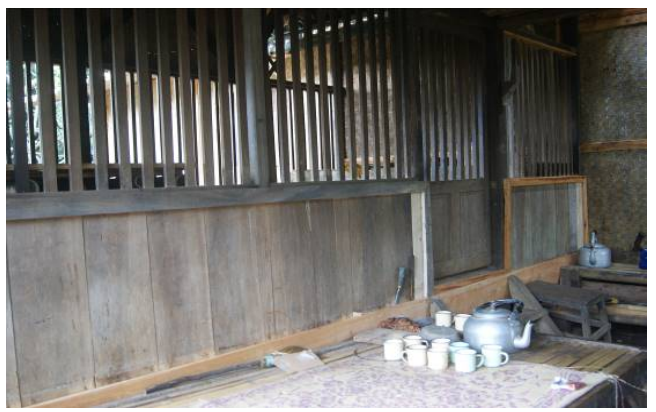

Gambar 9. Bale-bale luar Sumber: Dokumentasi penulis, Februari 2020.

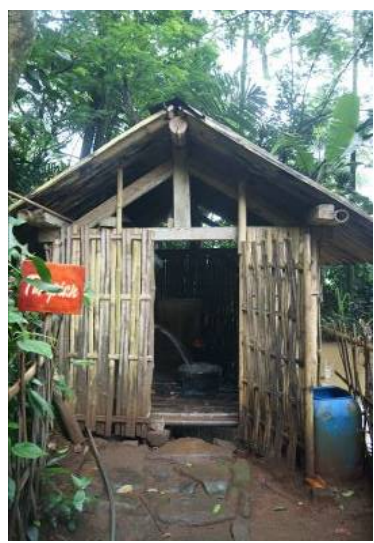

Gambar 11. Tampian (terpisah dengan rumah adat) Sumber: Dokumentasi penulis, Februari 2020

\section{Pergeseran Fungsi Ruang Rumah Adat Cikondang}

Fungsi ruang pada rumah adat seiring perkembangan zaman mengalami perubahan. Dahulu rumah adat digunakan sebagai tempat tinggal keluarga juru kunci. Namun seiring berkembangnya teknologi, keluarga juru kunci tidaklah lagi menempati rumah adat sebagai tempat tinggal. Selain itu, tahun 1980 Rumah Adat Cikondang telah diresmikan oleh pemerintah sebagai cagar budaya atau tempat wisata berbasis budaya dan religi adat (Juhana, wawancara pribadi. 2 Februari 2020).

\section{Bale-bale}

Dahulu bale-bale pada bagian luar difungsikan sebagai tempat menerima tamu jika belum diperbolehkan memasuki ruang tengah, dan sebagai ruang sementara bagi wanita atau salah satu anggota keluarga juru kunci yang sedang haid (tidak dalam keadaan suci). 
Selama tidak dalam keadaan suci, wanita tersebut sama sekali tidak boleh menginjak ke dalam rumah adat. Selain itu, fungsi bale-bale ini dahulu adalah sebagai area bagi istri ketua adat ketika menjalani prosesi kelahiran anak dan selama masih dalam keadaan nifas (belum suci) pasca prosesi kelahiran. Dahulu tamu yang tidak terlalu berkepentingan juga diterima di bale-bale. Namun ketika sudah diperbolehkan masuk, tamu akan menempati posisi di ruang tengah. Seiring berjalannya waktu, fungsi bale-bale beralih menjadi tempat penyimpanan tambahan alat makan dan minum untuk jamuan saat ritual upacara adat Wuku Taun pada 15 Muharram, karena sejak dibuka menjadi cagar budaya tidak hanya masyarakat setempat saja yang datang berkunjung tetapi juga wisatawan dan tim media pemberitaan dari luar. Fungsi tersebut telah sedikit berubah, namun aturan tetap diberlakukan bagi wanita yang sedang haid atau tidak dalam keadaan suci yaitu tidak boleh menginjak bagian dalam rumah adat.

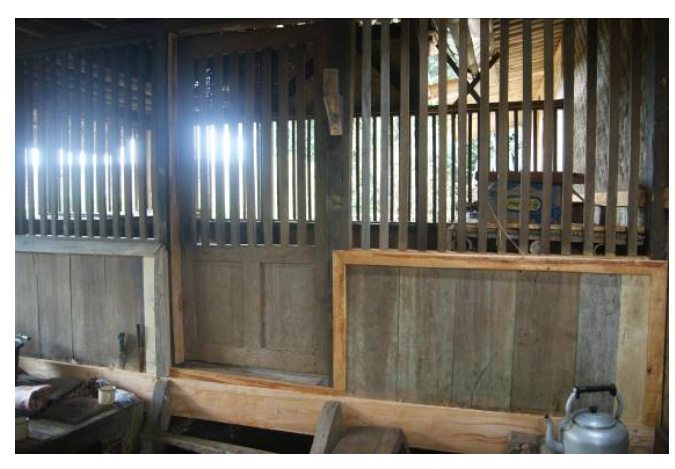

Gambar 12. Bale-bale luar

Sumber: Dokumentasi penulis, Februari 2020

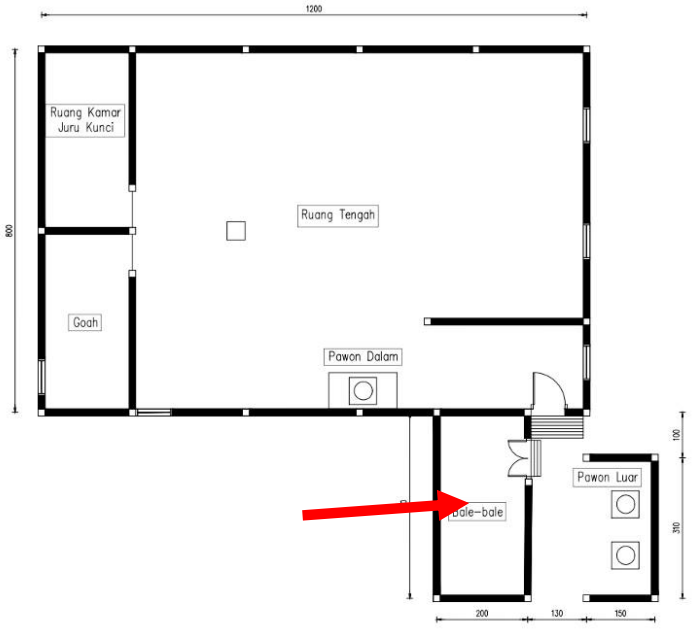

Gambar 13. Posisi bale-bale tampak denah layout Sumber: Digambar ulang oleh penulis, Februari 2020.

\section{Pawon Luar}

Pawon luar sejak dahulu sampai dengan saat ini tetap difungsikan sebagai tempat untuk memasak sehari-hari maupun saat dilaksanakannya persiapan ritual upacara adat. Fungsi pawon luar yang terdapat pada bagian luar rumah adat difungsikan sebagai tempat untuk memasak karena pawon dalam hanya boleh digunakan untuk memasak air dan nasi. Pawon 
luar digunakan untuk memasak bagi anggota keluarga juru kunci pada dulunya dan juga sekaligus digunakan untuk memasak saat ada persiapan perayaan-perayaan upacara adat. Pawon luar identik dengan kaum wanita, karena segala aktivitas yang berhubungan dengan memasak. Menata dapur merupakan tugas seorang wanita, sedangkan kaum laki-laki membantu mencari kayu bakar, namun kaum lelaki tetap boleh berada di area pawon luar.

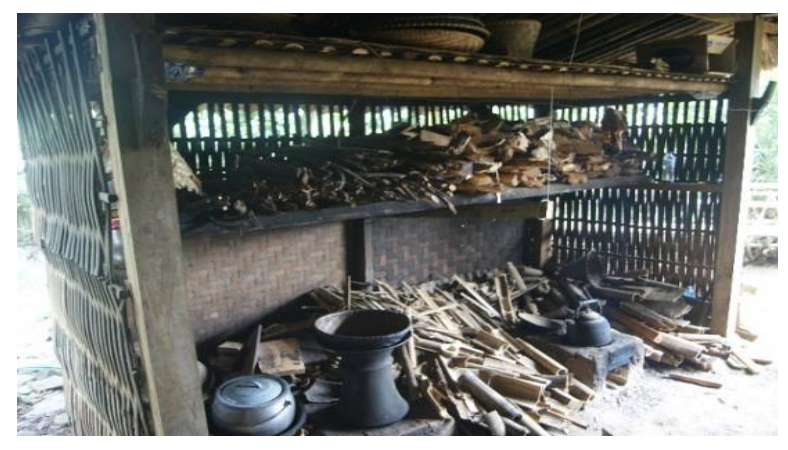

Gambar 14. Pawon luar Sumber: Dokumentasi penulis, Februari 2020

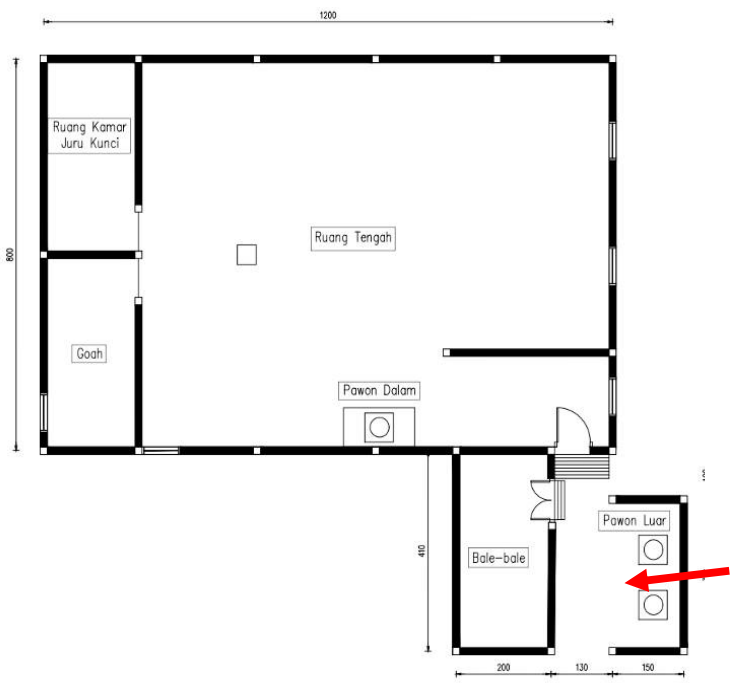

Gambar 15. Posisi pawon luar Tampak denah layout Sumber: Digambar ulang oleh penulis, Februari 2020

\section{Ruang tengah}

Bagian atau area lain yang berfungsi maksimal terdapat pada ruang dalam (tengah), tepat diatas ruang tengah terdapat pagok berupa lantai seperti palupuh sebelum plafon. Pagok terbuat dari bahan bambu yang berfungsi sebagai tempat penyimpanan makanan atau sejenisnya, namun lebih berfungsi maksimal ketika upacara adat. Bagian atas pagok masih di dalam ruang tengah rumah adat terdapat parak yang memiliki dua fungsi, yaitu selain sebagai plafon juga berfungsi sebagai tempat menyimpan dan sekaligus tempat untuk mengeringkan hasil panen pertanian berupa bawang. Hasil panen dapat kering dengan memanfaatkan panas dari atap, tentunya juga didukung oleh jarak yang relatif dekat antara atap paling atas dan bagian parak. 


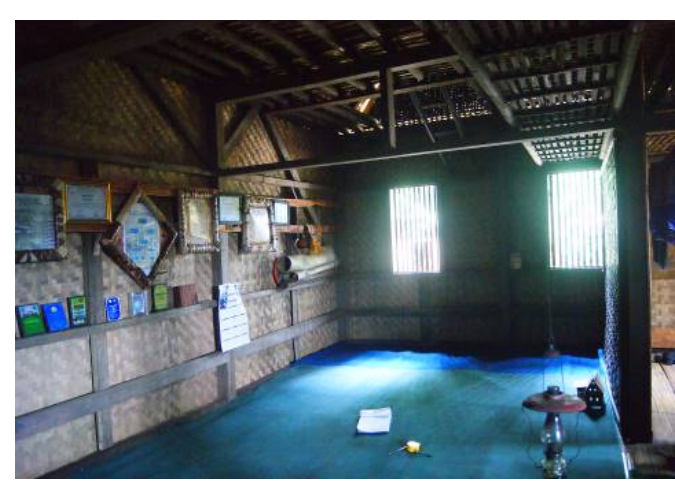

Gambar 16. Ruang tengah Sumber: Dokumentasi penulis, Februari 2020.

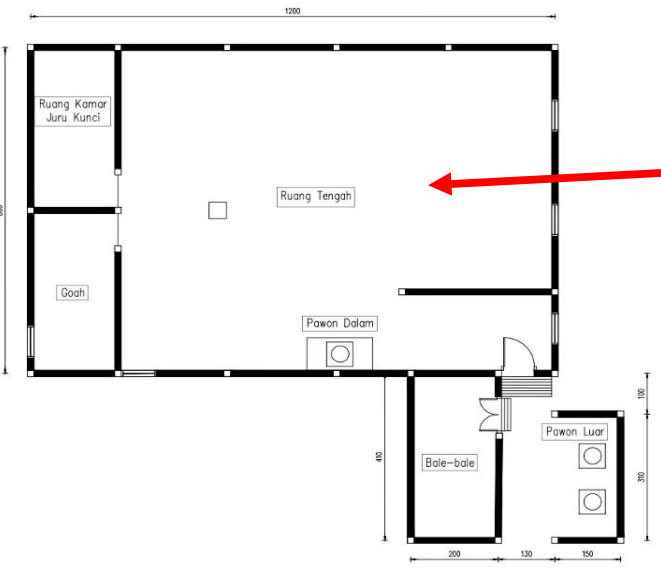

Gambar 17. Posisi ruang tengah tampak denah layout Sumber: Digambar ulang oleh penulis, Februari 2020.

Ruang tengah dahulu merupakan tempat berzona semi privat, dimana hanya orang-orang tertentu yang diperbolehkan memasuki rumah adat sesuai kepentingannya masing-masing dengan juru kunci atau salah satu anggota keluarganya. Seiring dengan perkembangan zaman dan membuka diri menjadi wisata cagar budaya, ruang tengah yang dulunya merupakan area zona semi privat menjadi zona publik, karena siapa pun sudah diperbolehkan mengunjunginya. Berbeda dengan saat dilaksanakannya ritual upacara adat, area tersebut sudah menjadi zona publik, karena dulunya maupun saat ini ruang tengah digunakan sebagai pusat dilaksanakannya inti acara ijab kabul upacara adat Wuku Taun, termasuk saat persiapannya.

\section{Pawon Dalam}

Pawon dalam yang menyatu dengan ruang tengah difungsikan sebagai tempat untuk menanak nasi dan memasak air merupakan area berzona publik, baik dulu hingga saat ini. Fungsi bagian pawon dalam digunakan sebagai tempat untuk memasak air dan nasi. Di dalamnya terdapat hawu yang digunakan sebagai perapian menghangatkan badan dan terdapat paraseuneu yang digunakan sebagai tempat menyimpan segala jenis bumbu dapur. Pawon dalam lebih berfungsi maksimal ketika dilaksanakannya persiapan perayaan utama / khas (Wuku Taun). Pawon dalam yang berhubungan dengan ruang tengah menjadi 
suatu akses yang efektif (dekat) untuk menyiapkan minum bagi tamu yang datang berkunjung dan berkumpul di ruang tengah. Pawon dalam ini dikelilingi oleh parako yang terbuat dari tanah liat, fungsinya sebagai pembatas antara hawu dan bagian lantai. Tempat bercengkrama tidak hanya dilakukan di ruang tengah, melainkan disekitar area dekat hawu sambil menghangatkan badan. Hal ini menjadi suatu kebiasaan yang dilakukan masyarakat adat dan menyebutnya sebagai kebiasaan sideang.

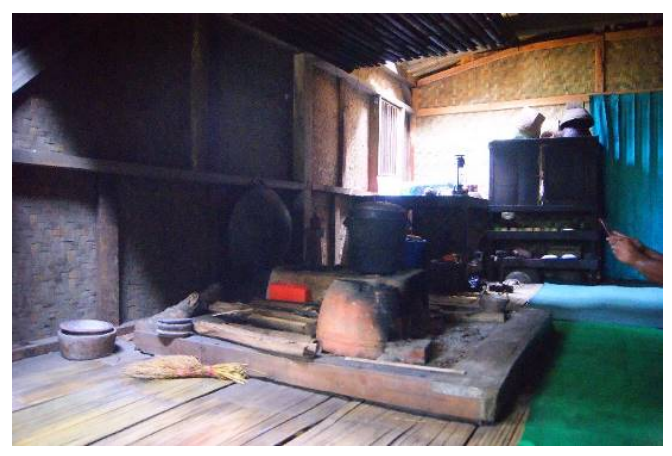

Gambar 18. Pawon dalam Sumber: Dokumentasi penulis, Februari 2020.

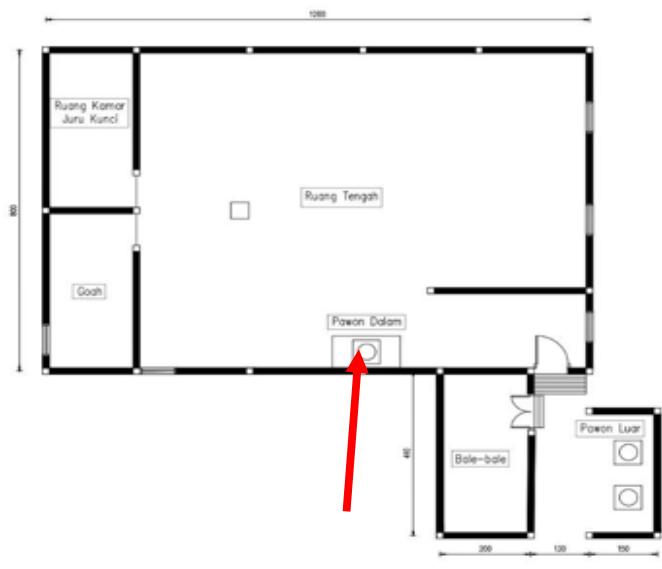

Gambar 19. Posisi pawon dalam tampak denah layout

Sumber: Digambar ulang oleh penulis, Februari 2020.

\section{Goah}

Ruang tempat penyimpanan beras atau goah merupakan area zona privat baik dulu maupun saat ini, karena hanya wanita yang diperbolehkan memasuki ruang tersebut. Lakilaki tidak diperbolehkan memasuki area ini, karena pada dasarnya goah hanya diperkenankan untuk wanita. Dahulu fungsi goah selalu difungsikan secara aktif namun saat ini tidak lagi berfungsi secara aktif, karena fungsi rumah adat yang sudah tidak dihuni atau ditempati oleh juru kunci yang saat ini memimpin. Fungsi rumah adat saat ini sudah tidak aktif seperti pada dulunya, dimana seluruh penataan, pemberian sajen (sesaji) dilakukan oleh adik perempuan dari seorang juru kunci, yang terpenting masih dari keturunan (wanita) pimpinan adat (yang memiliki wewenang). Fungsi goah kembali 
berfungsi ketika ada perayaan upacara adat yang akan dilakukan, misalnya saat melakukan persiapan upacara adat Wuku Taun. Seluruh aktivitas persiapan menata hidangan seperti tumpeng, maupun hidangan suguhan bagi tamu yang datang berkunjung.

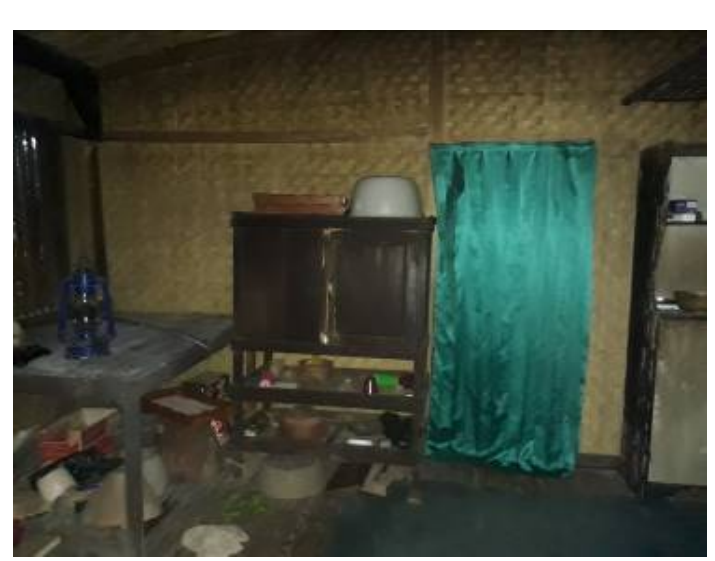

Gambar 20. Goah

Sumber: Dokumentasi penulis, Februari 2020

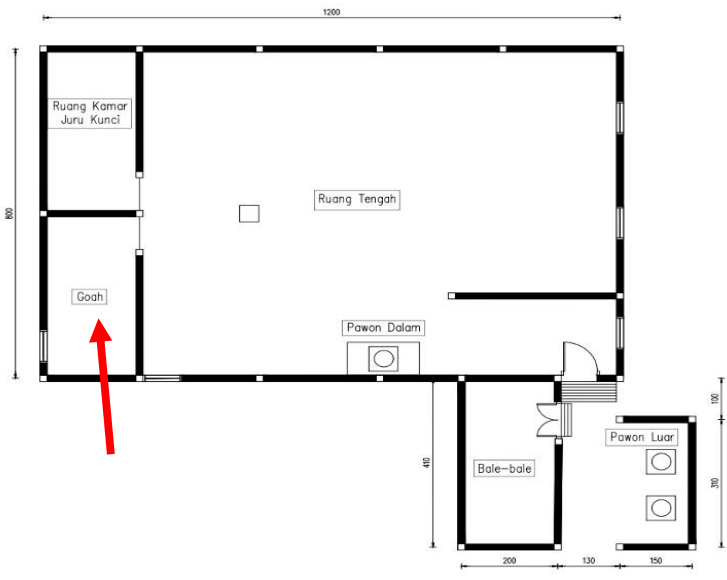

Gambar 21. Posisi goah tampak denah layout Sumber: Digambar ulang oleh penulis, Februari 2020.

\section{Kamar Juru Kunci}

Satu ruang disebelah kanan goah merupakan ruang kamar pribadi bagi juru kunci sebagai tempat beribadah dan menyimpan barang-barang pusaka. Area tersebut merupakan area berzona privat baik dulu maupun saat ini, karena tidak ada yang diperbolehkan membuka bahkan memasuki ruang kamar tersebut. Ruang kamar ini digunakan juga sebagai tempat penyimpanan benda-benda pusaka dan tempat untuk beribadah. Ruang pribadi juru kunci tidak boleh dimasuki selain oleh juru kunci, termasuk istri dan anak-anaknya. 


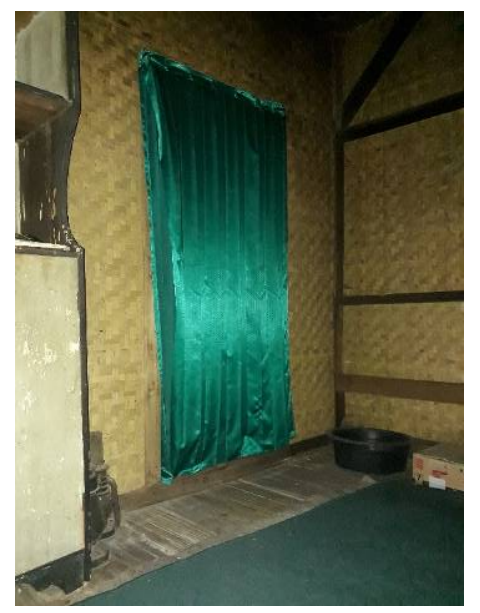

Gambar 22. Kamar juru kunci Sumber: Dokumentasi penulis, Februari 2020

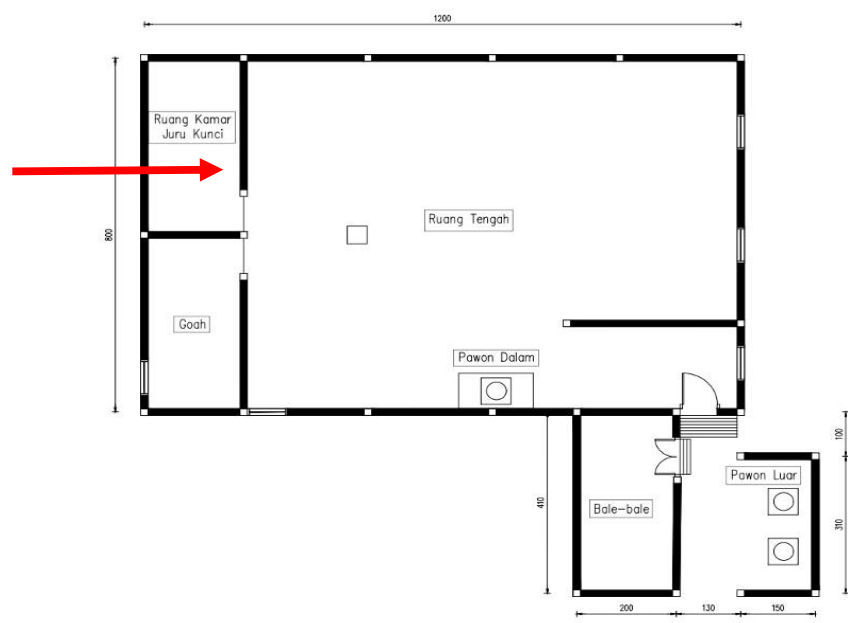

Gambar 23. Posisi kamar juru kunci tampak denah layout Sumber.. Digambar ulang oleh penulis, Februari 2020.

Analisis tersebut menunjukkan pergeseran fungsi ruang-ruang pada rumah adat begitu juga dengan klasifikasi teritorinya. Perubahan tersebut terlihat jelas sejak rumah adat ditetapkan menjadi wisata cagar budaya. Walaupun sudah terdapat pergeseran fungsi, aturan-aturan dalam rumah adat selalu dipatuhi oleh masyarakat adat maupun luar. Segala jenis kegiatan interaksi di dalamnya tetap merupakan suatu kesadaran bahwa ruang-ruang dalam rumah rumah adat ini tidak bersifat bebas begitu saja. Berikut merupakan perubahan klasifikasi teritori ruang-ruang dalam rumah adat.

Tabel 1. Analisis perubahan klasifikasi ruang

\begin{tabular}{|c|c|c|}
\hline RUANG & KLASIFIKASI TERITORI & $\begin{array}{c}\text { PERUBAHAN KLASIFIKASI } \\
\text { TERITORI }\end{array}$ \\
\hline Bale-Bale & Teritori Sekunder & Teritori Publik \\
\hline Pawon Luar & Teritori Sekunder & Teritori Publik \\
\hline Ruang Tengah & Teritori Sekunder & Teritori Publik \\
\hline Pawon Dalam & Teritori Sekunder & \\
\hline
\end{tabular}




\begin{tabular}{|c|c|c|}
\hline Goah & Teritori Primer & Teritori Primer \\
\hline Kamar Juru Kunci & Teritori Primer & Teritori Primer \\
\hline
\end{tabular}

Sumber: Analisis Penulis, 2020.

\section{Faktor - Faktor Pembentuk Teritorialitas}

\section{Mekanisme Defensif}

Batas-batas sebagai mekanisme defensif dilakukan dengan cara jelas maupun secara halus. Bagian bale-bale dan pawon luar seperti pada gambar pada bahasan sebelumnya ditandai dengan batas yang tegas, seperti bilik ruang yang terbuat dari potongan-potongan bambu dan anyaman bambu. Pawon dalam seperti pada gambar pada bahasan sebelumnya ditandai dengan batas yang cukup tegas dengan adanya batasan yang mengelilingi hawu atau perapian. Ruang tengah yang ditandai dengan batas secara halus dengan hanya suatu penyangga struktur di tengah ruang, namun ketentuan batas penempatan posisi secara tidak langsung dilakukan oleh juru kunci, sehingga masyarakat yang mengunjungi tidak menempatkan posisinya di depan maupun berdampingan dengan ketua adat.

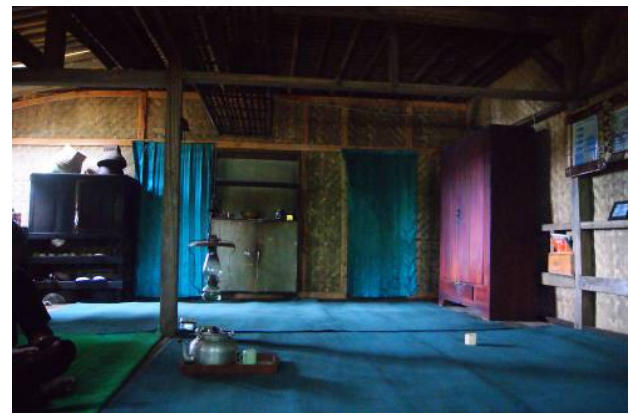

Gambar 11. Batas berupa tiang struktur di ruang tengah Sumber: Dokumentasi Penulis, Februari 2020.

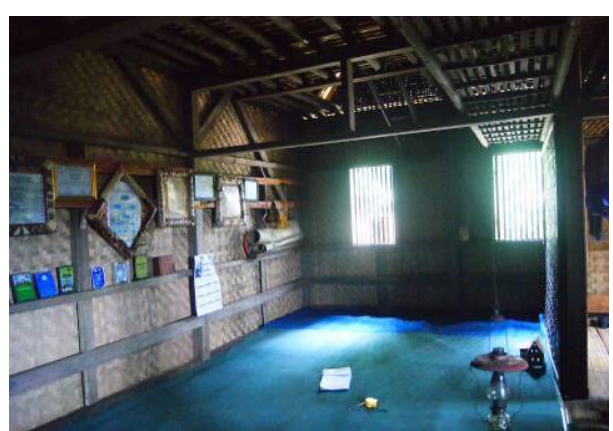

Gambar 12. Ruang tengah rumah adat Sumber: Dokumentasi Penulis, Februari 2020. 


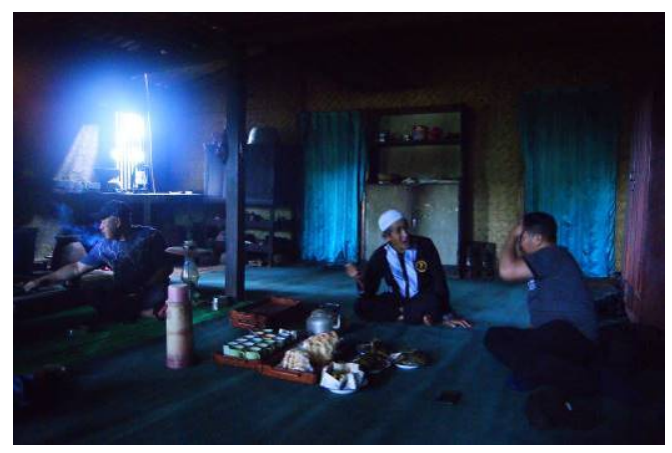

Gambar 13. Contoh penempatan posisi juru kunci dengan masyarakat luar Sumber: Dokumentasi Penulis, Februari 2020.

\section{Setting Fisik dan Perilaku Teritorialitas}

Teritorialitas merupakan atribut perilaku dimana atribut tersebut merupakan analisis yang mengambarkan hubungan antara individu (termasuk kumpulan individu yang membentuk kelompok) dan institusi atau organisasi dalam suatu sistem interaksi dan mengikutsertakan ruang atau merancang kegiatan (Weisman, 1981 dalam Burhanuddin, dkk, 2015).

Ruang-ruang pada Rumah Adat Cikondang merupakan ruang yang digunakan sebagai ruang publik saat melaksanakan ritual upacara adat, maupun jika dikunjungi oleh para wisatawan luar. Ruang tersebut memiliki keterkaitan atau hubungan dengan pembagian ruang dan batas teritori antar penggunanya. Walaupun sudah beralih fungsi, para masyarakat adat setempat dengan setting fisiknya timbul karena rasa memiliki terhadap rumah adat. Begitu juga dengan para wisatawan maupun masyarakat setempat dengan upaya kontrolnya terhadap penggunaan ruang.

Kontrol terhadap penggunaan interaksi dilakukan dengan penempatan kegiatan, mekanisme defensif dan keterikatan (Browel, 1976). Masyarakat adat setempat senantiasa melakukan kegiatan bersama dalam rumah adat berbentuk suatu musyawarah atau kegiatan ritual upacara adat. Ruang-ruang dalam rumah adat dirancang dengan sangat sederhana, namun tetap memperlihatkan batas-batas yang tegas baik langsung (secara 
menyolok) maupun secara tidak langsung. Batas-batas tersebut berupa bilik dinding yang membatasi di pertengahan ruang.

Area bilik berhadapan langsung dengan pintu rumah merupakan area bagi masyarakat umum atau wisatawan yang hadir saat upacara adat berlangsung, karena area untuk mayarakat adat setempat terutama yang sudah menjadi sesepuh lebih diutamakan mengisi area dalam pada ruang tengah. Batasan lain berupa tirai yang menutupi ruang goah dan kamar juru kunci digunakan sebagai cara untuk menutupi sesuatu yang bersifat privat di dalamnya. Selain itu, terdapat elemen ruang yang bisa disebut juga sebagai pintu depan untuk memisahkan area pawon luar, bale-bale dengan area dalam ruang rumah adat. Terdapat juga batas seperti perbedaan tinggi lantai dengan adanya golodog atau disebut juga dengan tangga kecil sebagai akses masuk ke dalam rumah.

Cara mekanisme defensif ini dilakukan secara halus untuk mencegah dan menghindar, sepertihalnya terdapat tiang penyangga di pertengahan ruang. Berdasarkan hasil pengamatan penulis selama melakukan penelitian, jika ada sekelompok orang atau individu yang sedang mengunjungi rumah adat, maka mereka tidak akan langsung melewati area belakang tiang, namun secara sadar langsung menempati tempat di depan tiang penyangga tersebut.

\section{Perilaku Teritorialitas}

Berbagai kegiatan yang berlangsung dalam Rumah Adat Cikondang baik kegiatan biasa seperti musyawarah warga, kunjungan wisatawan, maupun ritual upacara adat telah memperjelas batas bagi teritorinya. Selain itu pengguna dalam Rumah Adat Cikondang seperti masyarakat adat sadar akan mekanisme aturan, sehingga aktivitas pada saat persiapan ritual dilakukan dengan mematuhi aturan yang berlaku secara adat. Seperti halnya para wanita yang mempersiapkan makanan berada di dalam dan sekitar goah,

pawon dalam dan luar, sedangkan bagi laki-laki yang turut membantu, menempatkan 
posisi berkelompok di pinggir ruang tengah, sedangkan kamar juru kunci tetap tidak dibuka. Walaupun pada tahap persiapan acara ritual tertentu ruang di rumah adat dibuka, masyarakat setempat menyadari dan mematuhi aturan adat istiadat. Lima aspek utama

dari budaya yang tercermin dalam organisasi ruang dalam suatu rumah: 1. Struktur keluarga, 2. Peraturan Gender, 3. Sikap terhadap privasi, 4. Proses hubungan sosial (Rapoport, 1969).

\section{Protokoler dan Ritual}

Salah satu faktor yang memperkuat terjadinya teritorialitas adalah protokoler dan ritual. Ritual yang termasuk juga dalam budaya sangat berpengaruh pada teritorialitas dalam suatu ruang. Begitu banyak ragam perayaan tradisi di Kampung Adat Cikondang, namun di kampung adat ini memiliki satu jenis perayaan besar pada 15 Muharram yaitu perayaan Wuku Taun atau Seren Taun. Masyarakat adat senantiasa mempertahankan perayaan besar tersebut sebagai ucap rasa syukur kepada Tuhan Yang Maha Esa karena selalu memberikan berkah kehidupan, sebagai persembahan juga kepada Dewi Sri sebagai Dewi Padi (kesuburan) yang telah memberikan hasil panen yang melimpah, serta sebagai penghormatan kepada leluhur di kampung adat yang telah mewarisi tradisi adar istiadat secara turun temurun.

Rumah adat merupakan tempat satu-satunya sekaligus tempat utama dalam melaksanakan perayaan ritual Wuku Taun ini. Hal ini dilakukan karena rumah adat dianggap sebagai tempat suci dan masyarakat adat memiliki suatu rasa kepemilikan bersama. Masyarakat adat sebagai pengguna ruang dalam rumah adat khususnya saat perayaan ritual tentunya senantiasa memperhatikan protokol (aturan) yang harus dipatuhi sebagai cara bersikap dan juga penempatan. Penggunaan fungsi ruang dalam rumah adat terlihat sejak dilaksanakannya persiapan selama 14 hari. Persiapan ini membutuhkan ruang-ruang untuk melaksanakan kegiatan memasak dan juga berinteraksi satu sama lain, bahkan tidak jarang 
saat waktu persiapan tamu yang berasal dari luar kampung adat silih berganti berkunjung ke rumah adat.

Area pawon luar digunakan bagi kaum wanita dan kaum lelaki juga diperbolehkan untuk membuat hidangan makanan ringan, namun ketika hampir menjelang hari perayaan area pawon luar ini digunakan para wanita untuk memasak hidangan besar. Bale-bale digunakan dan diperuntukkan juga bagi kaum wanita dan kaum lelaki sebagai tempat untuk menyiapkan peralatan makan dan peralatan memasak. Ruang tengah digunakan dan diperuntukkan bagi kaum wanita dan lelaki yang mempersiapkan makanan yang harus dikemas menggunakan daun pisang dan juga sebagai area untuk menerima tamu (masyarakat luar) yang datang berkunjung. Begitu juga area pawon dalam yang digunakan dan diperuntukkan bagi siapa saja yang hendak memasak air dan sebagai area untuk menghidangkan minuman.

Hampir keseluruhan ruang-ruang tersebut digunakan dan diperuntukkan bagi siapa saja kecuali goah dan kamar juru kunci. Goah hanya digunakan kaum wanita saja sebagai area untuk mempersiapkan beras, sesaji dan sekaligus menjadi area tambahan untuk menyiapkan hidangan, namun kaum lelaki tidak diperbolehkan memasuki area ini tanpa terkecuali. Kamar juru kunci juga hanya digunakan dan diperuntukkan bagi juru kunci saja untuk mempersiapkan suatu persiapan yang bersifat khusus atau personal dalam menyambut perayaan besar ini khususnya.

\section{Hubungan antara keseluruhan faktor}

Hubungan antara pengguna teritori dengan setting kegiatan dalam ruang rumah adat Cikondang dilihat berdasarkan keterkaitan antara pengguna yaitu masyarakat adat setempat khususnya, masyarakat luar, dengan aktivitas, setting fisik, aturan-aturan adat sebagai protokoler dan ritual yang sangat berpengaruh kepada cara bersikap (tindakan) sehingga menciptakan suatu hubungan keterikatan holistik. Hubungan interaksi ini mulai terlihat saat masyarakat setempat atau luar melakukan aktivitas di dalamnya dengan tetap 
mematuhi aturan adat istiadat dan menempati posisi yang tepat sehingga mencegah adanya pelanggaran defensif. Selain keterikatan tersebut, ritual dalam rumah adat yang tetap dilaksanakan setiap tahunnya menimbulkan suatu rasa kepemilikan bersama karena keterikatan suatu organisasi masyarakat dan hubungan sosial antar masyarakat setempat

\section{PENUTUP}

Penelitian yang memfokuskan pada pergeseran fungsi ruang dan teritorialitas yang terjadi di dalam rumah adat terlihat hubungan antara faktor-faktor yang saling terkait. Teritorialitas yang terjadi dalam ruang-ruang rumah adat menciptakan suatu mekanisme yang teratur. Hubungan teritorialitas dalam penelitian ini tidak hanya melibatkan unsur setting fisik atau tempat dan pengguna teritori, tetapi juga keterikatan sosial yang kuat antar masyarakat adat setempat maupun luar, pergeseran fungsi yang masih mematuhi aturan, rasa kepemilikan yang tinggi dalam diri masyarakat adat sehingga menghasilkan wujud batas-batas yang jelas sebagai mekanisme defensif. Selain itu, objek pada rumah adat tersebut menjadikan suatu keseluruhan budaya yang membawa pengaruh besar terhadap cara bersikap (tindakan), aturan, kebiasaan yang tentunya berbeda dengan adat istiadat lainnya.

\section{UCAPAN TERIMAKASIH}

Dengan terselesaikannya artikel ilmiah ini, penulis mengucapkan terima kasih kepada:

1. Narasumber utama (Juru Kunci/Ketua Adat) Anom Juhana.

2. Ketua Karang Taruna Desa Lamajang, Rahmat.

3. Warga Masyarakat Adat Kampung Cikondang sebagai narasumber lain.

\section{DAFTAR PUSTAKA}

Altman. (1980). Human Behavior and Environment. Plenary Press, New York \& London.

Burhanuddin, Setioko, B. \& Suprapti, A. (2015). "Teritorialitas Ruang pada Jalur Penggal Jalan Kyai H.Agus Salim Kota Semarang" "Hubungan Perilaku Pengguna Teritori dengan 
Seting Jalur Jalan". Seminar Nasional "Menuju Arsitektur dan Ruang Perkotaan yang Berkearifan Lokal" PDTAP, Semarang, 12 Mei 2015, 55.

Fatimah, Dwi. (2010). Gender dalam Teritori. Jurnal Waca Cipta Ruang. Vol II (II), 1-8.

Indriani. Ni Ketut Ayu. (2019). Faktor-faktor Pembentuk Teritorialitas di Permukiman Kampung Jawa Kota Denpasar. Jurnal Sangkareng Mataram. Vol 5 (3), 32-40.

Hadinugroho, D.L.(2002). Ruang dan Perilaku Suatu Kajian Arsitektural. Artikel Ilmiah Arsitektur. Universitas Sumatera Utara Digital Library. 16 Hal.

Lang, Jon. (1987). Creating Architectural Theory: The Role of The Behavioral Sciences in Design, Privacy, Territoriality and Personal Space - Proxemic Theory. Van Nostrand Reinhold, New York.

Nuraini, R.D. \& Ikaputra. (2019). Teritorialitas dalam Tinjauan Ilmu Arsitektur. Jurnal INERSIA, Vol XV.(1), 12-22.

Nurhamsyah. (2016). Tipe Setting Teritori Teras Akibat Aktivitas Tambahan Penghuni di Permukiman Pesisir Sungai Kapuas. Vol 3(1), 1-14.

Rapoport, Amos. (1969). House Form and Culture. Englewood Cliffs, N.J.:Prentice Hall Rif'ati, Heni F. \& Sucipto, Toto. (2002). Kampung Adat dan Rumah Adat di Jawa Barat, Dinas Kebudayaan dan Pariwisata Propinsi Jawa Barat, Bandung. 